\title{
PERAN RESEPTOR MELANOKORTIN 1 PADA MELANOGENESIS
}

\author{
${ }^{1}$ Gunawan Pratama \\ ${ }^{1}$ Sunny Wangko \\ ${ }^{2}$ Jemima N. Jacobs
${ }^{1}$ Bagian Anatomi Histologi Fakultas Kedokteran Universitas Sam Ratulangi Manado
${ }^{2}$ Bagian Biokimia Fakultas Kedokteran Universitas Sam Ratulangi Manado
Email: pzkpfwIVTiger@yahoo.co.id

\begin{abstract}
Nowadays, natural or modified phenotype skin colors get more attention especially in social and cosmetic aspects. In fact, advanced biomolecular sciences have revealed a better understanding about controlling melanogenesis. In this molecular level, the complexity of melanin biopolymers produced in melanocytes is driven by melanocortin 1 receptors (MC1R). Coded by its genetic structure, this protein may affect receptors' affinity to their agonists or ligands. Then the intracellular cAMP dependent signal transduction will determine consequently the hair and skin colors. Transcription factors in the cAMP signal line in protein molecule forms are involved in determining enzyme synthesis which plays the main role in directing the biopolymer melanin's end products in endoplasmic reticulum, Golgi apparatus, and melanosome. Pheomelanogenesis is the consequense of melanocortin 1 receptors signal loss; its end product appears in yellow-red color melanin polymers. Understanding MC1R's signal transduction gives additional information about pigmentation abnormality in medical practice.
\end{abstract}

Keywords: MC1R, cAMP, transduction signal

\begin{abstract}
Abstrak: Dewasa ini fenotip warna kulit secara alami maupun dengan perlakuan banyak menjadi perhatian terutama dalam aspek sosial dan kosmetik. Seiring dengan itu, berbagai penelitian dan pengembangan biomolekuler yang bertujuan mengendalikan melanogenesis telah berkembang pesat. Pada tingkat molekul, proses kompleks biosintesis polimer melanin di dalam melanosit ditentukan oleh reseptor melanokortin 1 (MC1R). Struktur proteinnya yang dikode oleh faktor genetik seseorang dapat mempengaruhi afinitas reseptor terhadap agonis atau ligan. Selanjutnya jalur lintas sinyal transduksi bergantung siklik adenosin monofosfat (cAMP) intrasel yang dicetuskannya akan menentukan tipe dan warna kulit. Faktorfaktor transkripsi pada lintasan sinyal cAMP berupa molekul-molekul protein akan menentukan sintesis enzim yang memainkan peran kunci pada arah pembentukan biopolimer melanin di dalam retikulum endoplasma, aparatus Golgi dan melanosom. Feomelanogenesis dengan hasil akhir polimer melanin yang berwarna kuning kemerahan adalah jalur pasti hilangnya sinyal reseptor melanokortin 1 . Pemahaman pada lintasan sinyal reseptor melanokortin 1 setidaknya dapat memberi informasi pada kelainan pigmentasi dalam terapan ilmu kedokteran klinik medik.
\end{abstract}

Kata kunci: MC1R, cAMP, sinyal transduksi

Reseptor melanokortin 1 (MC1R) adalah suatu kelompok reseptor pasangan proteinG (GPCR) transmembran pada melanosit yang menjabarkan fenotip dari pigmen kulit, mengatur berbagai aspek fungsional dari melanosit termasuk stimulasi siklik adenosin monofosfat (cAMP), melanogenesis dan proliferasi. ${ }^{1} \quad$ Suatu endositosis bermedia reseptor, yang terjadi pada melanosit sebagai respon spesifik terhadap hormon peptida 
\{Hormon Adrenokortikotropin (ACTH)/alfa Melanocyte Stimulating Hormone $(\alpha \mathrm{MSH})\}$ adalah syarat utama untuk dapat memulai kaskade melanogenesis, dengan MC1R sebagai gerbang utama. ${ }^{2}$

Keluarga besar jenis reseptor Protein-G ini berfungsi memediasi beragam rangsangan, termasuk cahaya, penghidu, perasa, ionion, neurotransmiter dan hormon. Dalam pengaturan banyaknya sinyal tersebut, GPCR meregulasi aktivitas enzim-enzim metabolik, berbagai lintasan saluran ion, transpor membran, fungsi transkripsi, motilitas dan fungsi sekresi tergantung pada sel dimana protein tersebut berada. Melanocortin 1 receptor khususnya merupakan satu dari kelima jenis subfamili GPCR yang bertugas memediasi aktivitas fisiologi hormon peptida dalam menginduksi aktivasi siklik AMP dalam sitosol melanosit. ${ }^{3}$

Reseptor pasangan protein-G (GPC-R) adalah protein integral membran yang dikarakteristik dengan adanya tujuh domain hidrofobik transmembran (TM1-TM7) yang bersamaan membentuk jalinan heliks antiparalel alfa, terminal karboksil intrasel, terminal nitrogen ekstrasel, tiga lengkung ekstrasel dan tiga lengkung intrasel. ${ }^{4}$

\section{STRUKTUR PROTEIN}

Berdasarkan analisis kesamaan sekuensial, MC1R dan juga reseptor melanokortin lainnya digolongkan dalam GPCR kelas A dengan rodopsin sebagai prototipnya. ${ }^{5}$

Pada tahun $2000,{ }^{5}$ pertama kalinya struktur kristal GPCR mamalia yaitu rodopsin bovin, telah dapat diuraikan. Sementara ciri utama yaitu tujuh heliks transmembran diawetkan, orientasi relatif dari heliks secara signifikan berbeda dengan bakteriorodopsin. Baru kemudian pada tahun 2007, ${ }^{6}$ struktur GPCR manusia telah selesai diuraikan. Reseptor Melanokortin 1 (MC1R) adalah bagian integral membran yang tersusun dari 317 residu asam amino (Gambar 1) dengan struktur khas GPCR seperti antara lain; terminal $\mathrm{N}$ - bagian ekstra sel, tujuh fragmen transmembran (TM), dan terminal C-pada intrasel. $^{7,8}$

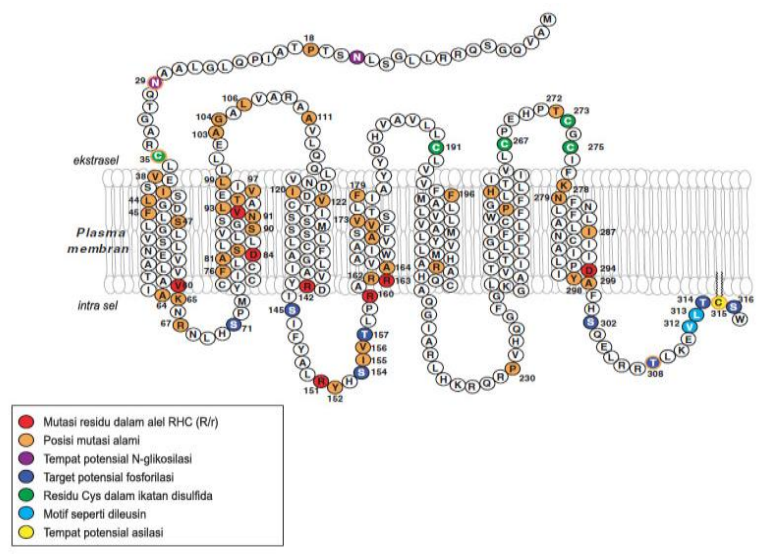

Gambar 1. Struktur protein reseptor melanokortin-1. Tersusun dari 317 residu asam amino dengan ciri khas umum dari GPCR yaitu: NTerminal ekstrasel, tiga lengkung ekstrasel, tujuh fragmen transmembran, tiga lengkung intrasel dan C-Terminal intrasel. Posisi transmembran heliks disesuaikan sedemikian dalam gambaran model 2D dari Ringholm, dkk, 2004. Sumber: Garcia-Borron dkk, $2005 .^{8}$

\section{AGONIS}

Dalam fungsinya sebagai reseptor pada membran melanosit, MC1R memerlukan suatu regulator atau bahan spesifik yang hanya dapat membuatnya tersensitisasi melalui ikatan ligan dengan bahan tersebut yang memenuhi kriteria tertentu.

\section{Melanokortin}

Melanokortin (Melanocortins) adalah suatu senyawa peptida bioaktif yang diproduksi oleh berbagai jaringan ekstraneural, termasuk kulit. Semua peptida melanocortin $\alpha-, \beta-$, dan $\gamma$ - melanocyte stimulating hormone $(\mathrm{MSH})$ dan hormon adrenokortikotropin (ACTH) memiliki aktivitas melanotropik tetapi juga memberikan banyak efek lain pada sel-sel kulit. Ekspresi melanokortin dan reseptornya memberi kesan bahwa setiap gangguan dengan regulasi kompleks autokrin atau parakrin akan selalu mempengaruhi homeostasis kulit. ${ }^{9}$

Alfa, beta dan gama $\{\alpha-, \beta-, \gamma-$ melanocyte stimulating hormone (MSH) $\}$ dan adrenocorticotropic hormone (ACTH) adalah produk pascatranslasi dari prohormon proopiomelanocortin (POMC). Sebagai li- 
gan alami yang berinteraksi dengan lima reseptor melanokortin (MC1R-MC5R), sintesis neuropeptida endogen dan hormon ini memainkan peranan penting dalam regulasi sejumlah besar fungsi fisiologi termasuk antara lain: pigmentasi kulit, fungsi adrenalkortikal, homeostasis energi, kebiasaan makan, fungsi seksual, fungsi kelenjar eksokrin, rangsangan nyeri, dan lain-lain. ${ }^{10}$

\section{Ikatan ligan-reseptor}

Melanocortin 1 receptor diaktifkan oleh hormon-hormon peptida spesifik (ACTH dan $\alpha-\mathrm{MSH}$ ) yang disintesis di hipofisis anterior, keratinosit dan tempat lainnya. Alfa MSH (Ac-Ser1-Tyr2-Ser3-Met4Glu5-His6-Phe7-Arg8-Trp9-Gly10-Lys11-Pro12Val13-NH2) tersusun dari 13 residu asam amino, melalui ikatan ligan-reseptor MC1R menginduksi cAMP dan mencetuskan sinyal transduksi menuju sintesis polimer melanin melalui prekursor DOPA. Segmen tertrapeptida His6-Phe7-Arg8-Trp9 dari $\alpha$-MSH juga terdapat pada struktur $\beta \mathrm{MSH}, \gamma \mathrm{MSH}$ dan ACTH telah diidentifikasi sebagai bagian penting (tetra peptida residu nomor 6 sampai 9) untuk interaksi efektif dengan reseptor melanokortin (MC). ${ }^{11,12}$

Jumlah tempat ikatan spesifik $\alpha-\mathrm{MSH}$ sedikit, secara normal melanosit manusia memperlihatkan ratusan molekul MC1R per-sel dan sel-sel melanoma sebaliknya menunjukkan berlimpahnya tempat ikatan agonis sampai seribu lebih per-sel. Pada keadaan densitas MC1R seperti ini mengakibatkan lebih banyak cAMP yang distimulasi oleh agonis pada kadar normal. ${ }^{8}$

Residu-residu asam dari MC1R antara lain: Glu94, Asp117, dan Asp121, bersama dengan Phe280, dan Asn281, diyakini membentuk ikatan yang berpotensi menjadi basis rantai samping Arg8 dari $\alpha$-MSH, dan residu-residu fenilalanin yang lain pada urutan: $175,179,195,196,257,258,288$, dan residu-residu triptofan pada urutan: 182, 183, dari reseptor ini dipostulatkan membentuk ikatan lainnya menjadi rantai samping Phe7, dan Trp9. ${ }^{8}$

Peran residu Trp9 $\alpha$-MSH dan ACTH dalam menentukan afinitas ikatan liganreseptor telah diuji coba secara in vitro dengan cara sintesis analog $\alpha-\mathrm{MSH}$ dan mengganti residu pada tempat nomor 9 (Trp9) dengan berbagai variasi asam amino lain. $^{12}$

\section{ANTAGONIS}

Reseptor melanokortin 1 selain disensitisasi oleh hormon peptida melanokortin itu sendiri, juga dihambat/desensitisasi oleh sejenis protein yang dinamakan Agouti signaling protein. Hal ini merupakan keadaan yang normal mekanisme umpan balik penguat dan pelemah dari berbagai proses fisiologi.

\section{Agouti signaling protein}

Agouti signaling protein (ASIP) pada manusia mencegah ikatan $\alpha$-MSH dengan MC1R dan menghambat efek $\alpha-$ MSH pada melanosit. Perlakuan pada melanosit manusia dengan $1 \mathrm{nM}-10 \mathrm{nM}$ rekombinan ASIP mencegah efek stimulasi $\alpha-\mathrm{MSH}$ pada akumulasi cAMP, aktivitas tirosinase dan proliferasi sel. ${ }^{13}$

Lokus agouti sebagai pengkode untuk agouti-signaling protein (ASIP), suatu faktor intrinsik yang terdapat pada sel-sel papila dermis dan folikel rambut (pada tikus), testis, jantung, hepar dan ginjal yang berfungsi sebagai regulator parakrin dari melanosit. Meskipun aksi ASIP secara in vivo atau in vitro sebagai antagonis sinyal $\alpha$ MSH dimediasi MC1R, mekanisme aksi yang pasti masih belum diketahui. ${ }^{14}$

Agouti signaling protein manusia tersusun dari 132 residu asam amino dan ini $80 \%$ identik dengan urutan asam amino pada homolog ASP tikus. Suzuki I, dkk. pada tahun $1997,{ }^{14}$ melaporkan bahwa ASIP bersaing dengan $\alpha-\mathrm{MSH}$ dalam ikatan ligan dengan MC1R. Agouti signaling protein pada manusia atau tikus keduanya juga menghambat aktivitas basal tirosinase dan proliferasi melanosit. Lebih lanjut, ASIP menghambat aktivitas beberapa agen yang meniru efek $\alpha$-MSH dan beraksi menurunkan fungsi MC1R. Melanosit pada folikel menghentikan sintesis eumelanin yang gelap setelah empat dekade pertumbuhan, pada saat itu ekspresi ASIP mengubah 
sintesis eumelanin ke feomelanogenesis. Blokade eumelanogenesis oleh ASIP diperhitungkan paling tidak karena hambatan kuat pada aktivitas enzim tirosin hidroksilase, dopa oksidase dan dopakrom tautomerase. $^{13}$

\section{SINYAL TRANSDUKSI}

Setelah reseptor melanokortin 1 tersensitisasi oleh agonisnya, maka serangkaian peristiwa fosforilasi dan aktivasi dari berbagai protein, enzim dan faktor-faktor transkripsi terjadi di dalam sitosol dan inti sel ditandai dengan meningkatnya kadar cAMP hingga akhirnya menentukan proliferasi dan kelangsungan hidup melanosit. Berikut di bawah ini dijabarkan jalannya peristiwa biokimiawi intrasel dengan melibatkan faktor-faktor terkait yang akan menuju proses melanogenesis.

\section{Functional Coupling}

Sinyal MC1R pertama kalinya dimulai setelah terikat dengan agonis diikuti dengan aktivasi dari protein-Gs heterotrimer dan stimulasi dari adenilil siklase. Akibatnya terjadi peningkatan kadar cAMP intrasel. Hal ini mencetuskan aktivasi dari protein kinase A (PKA). Umumnya cAMP bertanggung jawab pada peran melanogenesis dari $\alpha-\mathrm{MSH}$, termasuk aktivasi tirosinase, sebagian enzim yang dibutuhkan dalam biosintesis melanin, dan menggeser bentuk biosintesis feomelanin ke produksi eumelanin yang lebih gelap dan lebih foto protektif. Aktivitas tirosinase terutama muncul pada tingkat transkipsi dan dimediasi oleh induksi Microphthalmia (Mitf), suatu faktor transkripsi dari famili helix-loop-helix. ${ }^{7,8}$

\section{Jalur lintas sinyal bergantung cAMP}

Secara umum jalur lintas sinyal bergantung cAMP, protein-G subunit alfa $s$ teraktivasi akan terikat ke dan mengaktifkan suatu enzim yang dinamakan adenilil siklase yang kemudian mengkatalisis konversi dari ATP menjadi siklik adenosin monofosfat (cAMP). Meningkatnya kadar
cAMP sebagai second messenger akan diikuti aktivasi dari: ${ }^{7}$

- Siklik nukleotida-gerbang saluran ion.

- Lalulintas protein diaktivasi cAMP (EPAC) seperti RAPGEF3, atau

- Suatu enzim yang dinamakan 'protein kinase A'.

Protein kinase A (enzim PKA) juga dikenal sebagai enzim bergantung cAMP sebab enzim ini hanya akan aktif bila cAMP ada. Sekali PKA diaktifkan, enzim ini akan memfosforilasi berbagai protein lain termasuk: ${ }^{7}$

- Enzim-enzim yang mengkonversi glikogen menjadi glukosa.

- Faktor-faktor transkripsi yang meregulasi ekspresi gen.

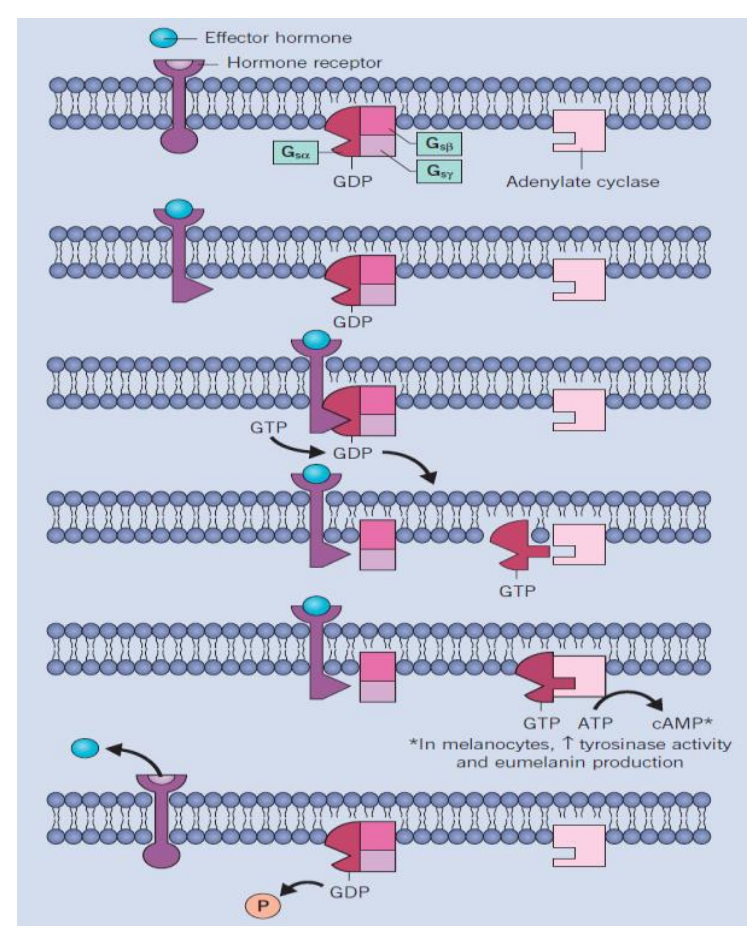

Gambar 2. Aktivasi reseptor melanokortin 1 (MC1R). Skema di atas menunjukkan peningkatan konsentrasi cAMP yang dicetuskan oleh functional coupling protein $\mathrm{G}$ dengan reseptor hingga terjadi perubahan konformasi. GTP yang selanjutnya menstimulasi adenilil siklase dalam mengubah ATP menjadi cAMP dan seterusnya sinyal transduksi menentukan sintesis melanin. (GDP=guanosin difosfat, GTP=guanosin trifosfat, $\mathrm{ATP}=$ adenosin trifosfat, $\mathrm{ADP}=$ adenosin difosfat). Sumber: Bolognia dan Orlow. ${ }^{15}$ 
Di dalam sel, cAMP terikat pada dua tempat sub-unit regulator dari protein kinase A, menyebabkan sub-unit terkatalisis menjadi aktif. Protein kinase A kemudian mampu memfosforilasi substratnya, termasuk saluran ion, enzim-enzim dan protein pengatur. Protein kinase A juga berpindah tempat ke dalam inti sel dimana ia juga memfosforilasi protein $c A M P$ responsive element binding protein (CREB) yang merupakan famili faktor-faktor transkripsi. Setelah mengalami fosforilasi, protein CREB kemudian mengaktivasi ekspresi gen spesifik yang berisi urutan $c A M P$ responsive element (CRE) di dalam promotornya (5'-TGACCTCA-3'). Protein kinase A juga memfosforilasi protein inti sel, CREBbinding protein (CBP) dimana interaksi dengan protein CREB dibutuhkan untuk ekspresi gen bergantung PKA. ${ }^{16}$

\section{Faktor-faktor transkripsi terkait dalam perjalanan sinyal}

\section{Microphthalmia Associated Transcription Factor (MITF)}

Microphthalmia Associated Transcription Factor memainkan peran penting dalam perkembangan melanosit dan kelangsungan hidupnya. Pada aplikasi klinisnya, mutasi MITF terdeteksi pada pasien-pasien dengan sindrom Waardenburg tipe II dimana terjadi penurunan pigmentasi pada kulit, mata, rambut, juga penurunan fungsi pendengaran. ${ }^{17}$ Faktor transkripsi MITF berbasis HLH (helix-loop-helix) yang berisi domain leucine-zipper dimana tempat tersebut bertanggung jawab untuk ikatan dengan DNA, motif HLH seperti ini dan domain leucinezipper sering terlibat dalam interaksi antar protein. Microphthalmia juga terlibat dalam pengaturan singkat gen tirosinase selama induksi melanogenesis-cAMP. Bertolotto dkk. $1998,{ }^{17}$ dalam percobaannya mende monstrasikan bahwa dengan adanya peningkatan kadar PKA (protein kinase A) juga diikuti dengan peningkatan microphthalmia pada senyawa mRNA dan protein. Aktivitas microphthalmia dibutuhkan oleh cAMP selama menginduksi stimulasi promotor tiro-

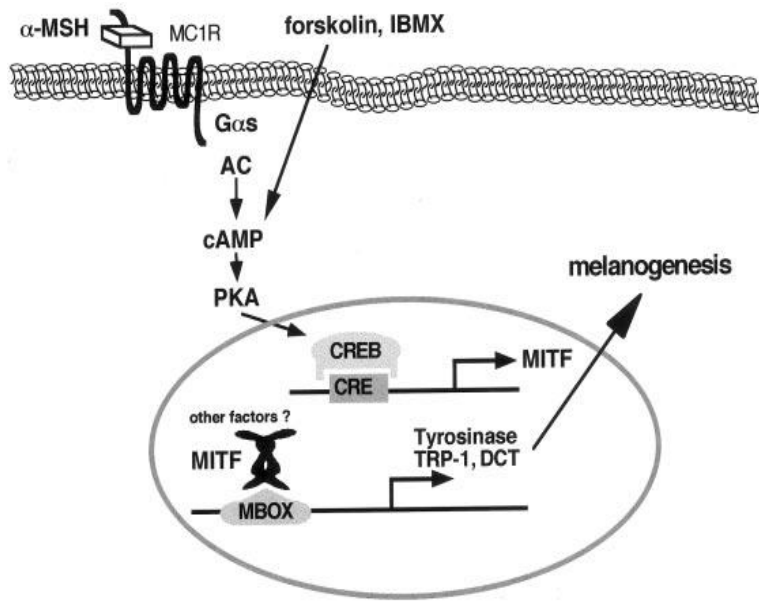

Gambar 3. Mekanisme regulasi induksi melanogenesis oleh sinyal transduksi cAMP dengan melibatkan MITF sebagai faktor transkripsi. ${ }^{13}$ $(\alpha-\mathrm{MSH}=$ alfa melanocyte stimulating hormone. $\mathrm{MC} 1 \mathrm{R}=$ melanocortin 1 receptor. $\mathrm{G} \alpha \mathrm{S}=\mathrm{G}$ protein sub unit $\alpha \mathrm{S}$. $\mathrm{AC}=$ adenilil cyclase. $\mathrm{cAMP}=$ siklik adenosin monofosfat. $\mathrm{PKA}=$ protein kinase $\mathrm{A}$. $\mathrm{CREB}=\mathrm{cAMP}$ responsive element binding protein. $\mathrm{CRE}=\mathrm{CAMP}$ responsive element. $\mathrm{MITF}=$ microphthalmia associated transcription factor. TRP-1=tyrosinase related protein 1. DCT=dopachrome tautomerase). Sumber: Busca and Ballotti, 2000. ${ }^{16}$

sinase, oleh karena itu cAMP meningkatkan ekspresi microphthalmia dalam mengikat promotor tirosinase yang dinamakan $M$-box, selanjutnya akan menuju pada stimulasi ekspresi tirosinase dan sintesis melanin. ${ }^{16}$ Meningkatnya ekspresi MITF disusul dengan bertambahnya ikatan dengan E-box dan $M$-box yang terdapat dalam promotorpromotor tirosinase dan berakibat pada meningkatnya ekspresi tirosinase serta meningkatnya regulasi sintesis melanin.

\section{Protein-protein SOX (HMG box tipe SRY)}

Protein SOX adalah faktor transkripsi yang secara predominan memiliki peran dalam perkembangan melanosit. Faktor transkripsi tersebut tergolong dalam high mobility group (HMG) box superfamili protein pengikat DNA. Selama perkembangan melanosit dari celah neural, SOX10 mengatur MITF yang nantinya mengontrol gen $\mathrm{u}$ tama dalam pigmentasi, termasuk dopakrom dan dopakrom tautomerase. Di samping itu 


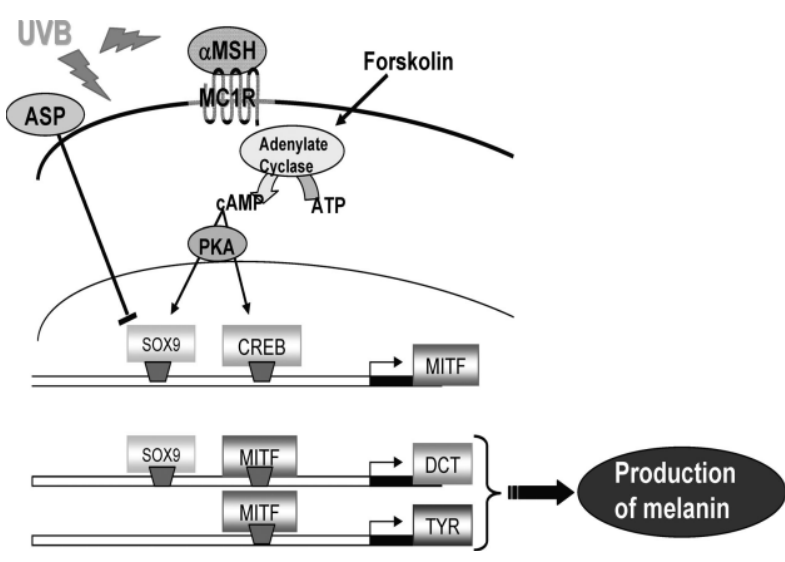

Gambar 4. Representasi skema peran dari SOX9 dalam pengaturan pigmentasi. Radiasi UVB, seterusnya mengaktifasi PKA via cAMP, meningkatkan ekspresi SOX9 dan CREB. Kedua faktor transkripsi meregulasi promotor MITF. SOX9 dan MITF kemudian bersamasama meregulasi promotor DCT. Pada saat yang sama MITF juga beraksi pada promotor tirosinase yang pada akhirnya menuju produksi melanin didalam melanosom. (UVB=ultra violet B. $\mathrm{ASP}=$ agouti signaling protein. $\mathrm{SOX}=$ faktor transkripsi). Sumber: Passeron dkk, 2007. ${ }^{18}$

SOX10 beraksi sebagai transaktivator penting dari DCT dimana MITF sendiri tidak cukup menstimulasinya. ${ }^{18}$

\section{REGULASI BIOSINTESIS MELANIN}

Pra zat (prekursor) dari aktifitas produksi melanin, baik eumelanin yang coklathitam dan feomelanin yang berwarna kuning-merah adalah asam amino tirosin. Enzim-enzim utama dalam lintasan produksi melanin adalah tirosinase, asam 5, 6-dihidroksiindol-2-karboksilat oksidase (DHICA oksidase) / tyrosinase related protein-1 (TRP-1) dan DOPAchrome tautomerase (DCT) / tyrosinase related protein-2 (TRP2). ${ }^{15}$

Aktivitas tirosinase merupakan enzim kunci dari biosintesis melanin baik eumelanin atau feomelanin. Feomelanogenesis adalah jalur pasti pada hilangnya sinyal MC1R, ditandai dengan aktivitas tirosinase yang sangat rendah dan tingginya konsentrasi sistein. Sebaliknya, sintesis eumelanin memerlukan terikatnya alfa MSH dan MC1R seterusnya melalui sinyal transduksi

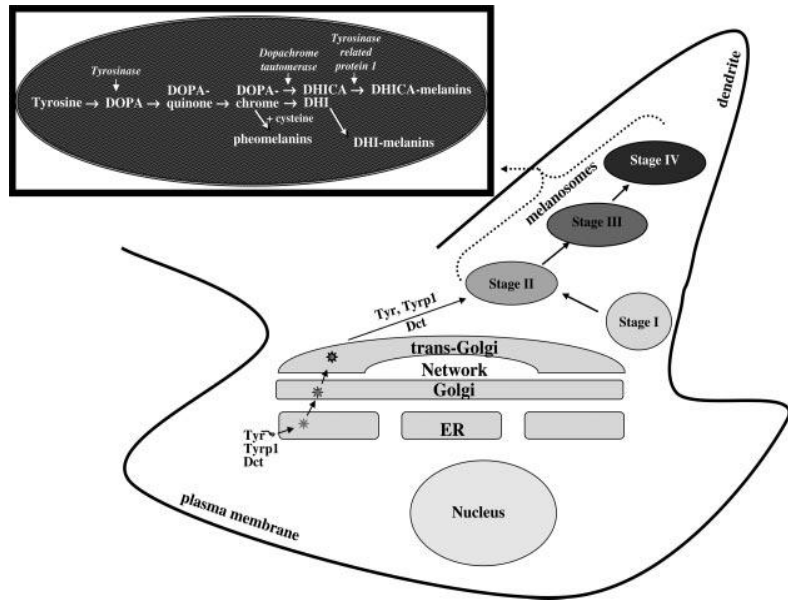

Gambar 5. Skema proses perkembangan melanosom dalam melanosit. Empat tingkat perkembangan melanosom berpindah ke daerah perifer sampai ke ujung dendrit sel. Tanda bintang melambangkan tahapan glikosilasi yang membentuk protein-protein melanogenik seiring transpor bahan tersebut melewati retikulum endoplasma dan aparatus Golgi. Sumber: Costin and Hearing, 2007. ${ }^{21}$

yang panjang berakhir pada aktivasi tirosinase dan meningkatkan regulasi tyrosinase related protein-1 (TRP-1) dan dopakrom tautomerase: produk dari lokus DCT dengan nama formal TRP-2. Enzim-enzim tersebut adalah glikoprotein yang membutuhkan karbohidrat dalam menjalankan fungsinya. Setelah mengalami modifikasi pascatranslasi di dalam retikulum endoplasma dan aparatus golgi kemudian bergabung dengan matriks protein membentuk melanosom. Gen lain seperti ASP, antagonis alfa MSH berperan sebagai hambatan ringan pada aktivitas tirosinase dan blokade total pada ekspresi TRP-1 dan TRP-2. ${ }^{19}$

Dalam banyak literatur telah dapat diterima bahwa sintesis melanin dimulai dengan hidroksilasi L-tirosin menjadi L-dihidroksifenilalanin (L-DOPA). Hidroksilasi tersebut merupakan tahap terbatas jalur sintesis yang dikatalisis oleh tirosinase. Tahap ini diikuti oleh beberapa rangkaian reaksi oksidasi dan reduksi untuk membentuk pigmen melanin. Dihidroksifenilalanin (L-DOPA), produk dari hidroksilasi L-tirosin berfungsi sebagai prekursor pigmen eumelanin dan feomela- 
nin. Tergantung genotip dari masing-masing individu dan lingkungan sel, melanogenesis menghasilkan pigmen gelap eumelanin, pigmen kuning-kemerahan feomelanin, atau campuran kedua komponen. ${ }^{20}$

\section{ASPEK KLINIS TERKAIT}

Aspek klinis berdasar hubungan pembahasan molekuler MC1R dan melanogenesis dengan penggunaanya pada ilmu kedokteran paling sering dikaitkan dengan penentuan tipe kulit, kecenderungan terhadap kanker melanoma dan kelainan pigmentasi lain yang berhubungan dengan MC1R.

Seperti yang telah diungkapkan sebelumnya bahwa melanogenesis yang diatur melalui jalur lintas sinyal transduksi oleh MC1R yang memberikan gambaran setidaknya perbedaan warna kulit manusia sangat dipengaruhi oleh faktor genetik yang mengkode reseptor tersebut. Beberapa variasi pada urutan residu dari 317 asam amino reseptor tersebut juga telah dapat diidentifikasi dengan penelitian-penelitian sebelumnya dan menyimpulkan hasil yang sama. (Valverde dkk. 1995, ${ }^{22}$ Harding dkk. $2000 .^{23}$ )

\section{Tipe kulit dan kerentanan terhadap kan- ker melanoma}

Predisposisi terjadinya melanoma lebih tinggi pada tipe kulit I dan II skala Fitzpatrick yaitu kulit terang, pirang, atau rambut merah dan kulit yang tidak memiliki kemampuan menggelap dan selalu terbakar matahari. Terdapat enam varian kodon MC1R yang selalu dihubungkan dengan melanoma maligna yaitu: Arg160Trp, Asp 294His, Val60Leu, Val92Met, Ile155Thr dan Arg163Gln. ${ }^{24}$

Valverde dkk $1996,{ }^{25}$ dalam laporannya mendapati varian Asp84Glu MC1R hampir pasti hanya terdapat pada melanoma. Selain itu terdapat varian Asp294His (aspartat diganti dengan histidin pada urutan 294) pada kasus lain Asn91 Asp juga tidak terdapat pada kulit normal dibanding varian Val92Met yang memiliki frekuensi sama dengan kelompok kontrol (normal).
Strategi mencegah timbulnya kanker kulit melanoma dapat ditempuh dengan perlakuan terhadap MC1R dengan membuat analog agonisnya. Abdel Malek, $2006,{ }^{26}$ mengemukakan strategi pencegahan melanoma dengan tiga macam sintesis tetrapeptida alfa MSH yang lebih berafinitas kuat dengan reseptor melanokortin 1 dibanding dengan $\mathrm{MSH}$ alami (Ac-His-DPhe-Arg-Trp-NH2, n-Pentadecanoyl dan 4Phenylbutyryl-His-D-Phe-Arg-Trp-NH2), dan telah diujicobakan pada kultur melanosit dengan hasil akhir di antaranya: stimulasi aktivitas tirosinase, mengurangi apoptosis dan pelepasan hidrogen peroksida serta memperkuat perbaikan fotoproduk DNA (kerusakan DNA dan mutasi) akibat paparan radiasi sinar ultra violet.

\section{Pigmentasi berlebih yang disebabkan faktor internal}

Hiperpigmentasi seringkali terlihat dalam masa kehamilan dimana keadaan ini dikenal dengan melasma, kloasma, atau tabir kehamilan. Kelainan tersebut terjadi terutama pada daerah leher, bawah hidung, dagu dan dahi dengan ciri khas berupa hipermelanosis simetris dengan warna yang tidak merata antara coklat terang sampai abu-abu dan coklat gelap. Meskipun melasma selalu dikaitkan dengan kehamilan, faktor-faktor lain juga dapat mempengaruhi kelainan tersebut di antaranya: pajanan sinar matahari, terapi hormon, kontrasepsi oral terkandung estrogen, genetik, bahan aktif kosmetik tertentu, endokrin, kegagalan hati dan obat-obatan anti epilepsi. ${ }^{21}$

Daerah yang mengalami hiperpigmentasi terjadi penumpukan melanin tanpa adanya pertambahan jumlah melanosit, tetapi terjadi peningkatan aktivitas, pertambahan ukuran dan perpanjangan dendrit dari melanosit. Selama masa kehamilan (terutama pada trimester ketiga) terjadi peningkatan estrogen, progesteron dan MSH selalu dikaitkan dengan kemunculan melasma. ${ }^{21} \mathrm{Me}$ kanisme pigmentasi dalam keadaan ini dapat dimengerti setelah beberapa penjelasan pada sub-bab sebelumnya menyangkut aktivasi reseptor melanosit oleh hormon efek- 
tor meskipun jalur lintas sinyal transduksi oleh estrogen dan beberapa hormon steroid lainnya mungkin tidak berhubungan dengan MC1R tetapi dengan konsep pemahaman yang sama.

\section{Vitiligo dan aktivitas sinyal transduksi}

Vitiligo umumnya terdapat pada kelainan herediter sindrom poliendokrin autoimun tipe I (APS I). Penderita dengan APS I diketahui memiliki titer autoantibodi yang tinggi langsung berlawanan dengan berbagai spesifik antigen jaringan. Gen yang bertanggung jawab pada sindrom ini telah dapat diidentifikasi dan dikenal dengan regulator autoimun (AIRE), sebagai pengkode protein dengan karakteristik faktor-faktor transkripsi. ${ }^{27}$

Auto antibodi yang merusak melanosit telah banyak dilaporkan pada penderita vitiligo yang berhubungan dengan APS I, tetapi autoantigen utama penyebab vitiligo masih belum diketahui. Peran yang mungkin berpengaruh menyangkut tirosinase, tirosinase related protein-1 (TRP-1) dan tirosinase related protein-2 (TRP-2), enzimenzim kunci dalam sintesis melanin dan pengatur matriks glikoprotein melanosom, pmel17, dalam hubungannya dengan autoantigen melanosit masih sangat kurang diketahui. ${ }^{28}$ Walaupun demikian, Hedstrand $\mathrm{dkk},{ }^{27}$ dalam penelitiannya mendapati bahwa hampir setiap pasien vitiligo dijumpai adanya peningkatan hiperreaktif titer autoantibodi faktor transkripsi SOX9 dan SOX10 dan mengindikasikan peran yang lebih banyak dari autoantigen SOX10 pada vitiligo. Adanya gangguan pada faktor transkripsi tersebut dapat mempengaruhi sintesis melanin dalam jalur sinyal transduksi di dalam inti sel sebagaimana telah dijelaskan pada sub-bab sebelumnya mengenai protein-protein terkait dalam sinyal transduksi.

\section{PEMBAHASAN}

Melanogenesis adalah suatu proses kompleks dari biosintesis polimer melanin dalam melanosit melalui berbagai pencetus dan jalur lintas sinyal intrasel yang meli- batkan banyak sekali protein terkait dalam suatu konteks keseimbangan homeostasis kulit. Reseptor melanokortin 1 (MC1R) adalah satu-satunya regulator utama dalam biosintesis melanin di samping faktor lain yang dapat mencetuskan melanogenesis. Reseptor melanokortin 1 selain berperan dalam sintesis eumelanin juga berperan dalam proliferasi melanosit, termasuk sifat dendrisitas melanosit.

Peran MC1R pada melanogenesis sangat bergantung pada agonis dan antagonisnya, selain itu struktur polipeptida reseptor tersebut sangat menentukan afinitas ikatan terhadap agonisnya hingga menentukan kuat-lemahnya sinyal transduksi dengan hasil akhir pemilahan sintesis eumelanin atau feomelanin. Variasi struktur polipeptida reseptor selain dikode oleh faktor genetik juga terjadi akibat mutasi alami dengan konsekuensinya berupa keragaman fenotip tipe kulit dan kerentanan terhadap kanker kulit.

Sintesis eumelanin yang gelap hanya dapat terjadi jika terdapat enzim dopakrom tautomerase yang hanya dapat menjadi aktif oleh adanya sinyal MC1R oleh karenanya feomelanogenesis adalah jalur pasti pada tidak adanya sinyal MC1R meskipun enzim tirosinase masih dapat aktif melalui jalur lain non MC1R.

Keseluruhan proses melanogenesis dimulai dari aktivasi pada reseptor melanosit, functional coupling, proses pra-cAMP, proses pasca-cAMP, proses pascatranslasi, proses pada tingkat enzim sampai pada produk eumelanin atau feomelanin memberikan gambaran bahwa setiap kelainan pigmentasi kulit dapat dibedakan berdasarkan pada gangguan dari seluruh tahapan tersebut. Misalnya pada sindrom Cushing dengan salah satu manifestasi klinis berupa hiperpigmentasi kulit akibat peningkatan sekresi ACTH eksogen yang kemudian mengaktivasi reseptor melanosit begitu juga dalam keadaan fisiologis masa kehamilan terjadi peningkatan kadar $\mathrm{MSH}$, ACTH, estrogen dan progesteron hingga menyebabkan hiperpigmentasi areola mamae dan beberapa regio lain. Mekanisme pigmentasi dalam keadaan ini dapat dimengerti setelah 
beberapa penjelasan pada sub-bab sebelumnya menyangkut aktivasi reseptor melanosit oleh hormon efektor meskipun jalur lintas sinyal transduksi oleh estrogen dan beberapa hormon steroid lainnya mungkin tidak berhubungan dengan MC1R tetapi dengan konsep pemahaman yang sama. Sebaliknya pada albinisme terjadi gangguan pada tahap pascatranslasi dan gangguan enzim dimana tirosinase sama sekali tidak ada meskipun sinyal transduksi berjalan normal, reseptor sampai pasca cAMP berjalan normal sehingga hasil akhir berupa feomelanogenesis.

Pada akhirnya, pembelajaran pada reseptor melanosit secara tidak langsung juga memberikan pemahaman tentang cara kerja kelompok reseptor protein G (GPCR) lain pada sel yang lain mengingat kebanyakan obat-obatan ditargetkan pada reseptor protein $\mathrm{G}$ ini dan memberi beragam aktivitas sinyal pada tahap biomolekul dalam upaya memperbaiki dan mengendalikan keadaan abnormal dari berbagai kelainan akibat dari suatu penyakit.

\section{KESIMPULAN}

Reseptor melanokortin 1 pada melanosit adalah regulator utama yang mempengaruhi tidak hanya pada proses biosintesis polimer melanin dalam melanosit tetapi berpengaruh juga pada sifat dendrisitas dan proliferasi.

Adrenokortikotropin hormon dan MSH adalah hormon efektor yang spesifik terhadap reseptor melanokortin 1 disebabkan oleh adanya patahan penting struktur polipeptida yang berafinitas dengan asam amino pada beberapa tempat tertentu dalam struktur reseptor melalui ikatan ligan-reseptor. Dengan dasar ini, memungkinkan untuk membuat analog sintetik peptida tersebut untuk mengontrol kelainan pigmentasi.

\section{DAFTAR PUSTAKA}

1. Le Pape E, Passeron T, Giubellino A, Valencia JC, Wolber R, Hearing VJ. Microarray analysis sheds light on the dedifferentiating role of agouti signal protein in murine melanocytes via the
Mc1r. PNAS. [serial online]. 2009 Feb 10 [cited 2009 Apr 12]; 106(6): 1802-7. Available from: DOI: 10.1073/pnas.0806 753106.

2. Cormack DH. Ham histology. Jilid I, ed $9^{\text {th }}$. Jakarta: EGC, 1994; p.133.

3. Rees JL. The melanocortin 1 receptor (MC1R): more than just red hair. Pigmen Cell Res [serial online]. 2000 [cited 2009 Apr 12]; 13: 135-40. Available from: http://www.derm.med.ed.ac.uk/PDF/more thanjustredhair.pdf

4. Ramanathan, Chandra S, Gopal, Shuba. Polynucleotides encoding a human Gprotein coupled receptor, HGPRBMY39 (US Patent 7198912). Free Patents Online [homepage on the internet] 2007 Apr 3 [cited 2009 Apr 12]. Available from: URL: http://www.freepatentsonline.com/ 7198912.html.

5. Palczewski K, Kumasaka T, Hori T, Behnke CA, Motoshima H, Fox BA, et al. Crystal structure of rhodopsin: A G protein-coupled receptor. Science [serial online]. 2000 [cited 2009 Apr 12]; 289 (5480): 739-45. Available from: DOI: 10.1126/science.289.5480.739.PMID109 26528.

6. Rasmussen SG, Choi HJ, Rosenbaum DM, Kobilka TS, Thian FS, Edwards PC et al. Crystal structure of the human $\beta 2$-adrenergic G-protein-coupled receptor. Nature [serial online]. 2007 [cited 2009 Apr 12]; 450 (7168): 383-7. Available from: DOI: 10.1038/nature06325. PMID17952055.

7. Wikimedia Foundation, Inc. G proteincoupled receptor. Wikipedia ${ }^{\circledR}$ [homepage on the Internet]. 2009 [cited 2009 Apr 12]. Available from: URL: http://en. wikipedia.org/wiki/G_protein-coupled_ receptor.

8. Garcia-Borron JC, Sanchez-Laorden BL, Jimenez-Cervantes C. Melanocortin-1 receptor structure and functional regulation. Pigment Cell Res [serial online]. 2005 [cited 2009 Apr 12]; 18: 393-410. Available from: URL: http://www 3.interscience.wiley.com/cgibin/fulltext/118701 451/ PDFSTART.

9. Böhm M and Luger TA. The Role of Melanocortins in Skin Homeostasis. Horm Res 54: 287-293. [serial online] 2000. [cited 2009 Apr 12]. Available from: URL: http: //content.karger.com/ProdukteDB/produk 
te.asp?Doi=53273\#OLN

10. Ying J, Gu X, Cai M, Dedek M, Vagner J, Trivedi Dev B, et al. Design, Synthesis, and Biological Evaluation of New Cyclic Melanotropin Peptide Analogues Selective for the Human Melanocortin-4 Receptor. J Med Chem 16; 49(23): 68886896. [serial online] Nov 2006. [cited 2009 Apr 12]. Available from: URL: http://www.pubmedcentral.nih.gov/picren der.fcgi?artid $=1764620 \&$ amp;blobtype $=p$ df.

11.Humphrey, Stuart, Michael. A method of inducing melanogenesis in humans with MC1R variant alleles. World Intelectual Property Organization. [homepage on the Internet] 2005 Feb 06, Pub. No: WO/2005/0489 67. [cited 2009 Jul 04]. Available from: URL: http://www.wipo. int/pctdb/en/wo.jsp?wo=2005048967.

12.Bednarek MA, MacNeil T, Tang R, Fong TM, Cabello A, Maroto $M$, et al. Analog of $\alpha$-Melanocyte Stimulating Hormone with High Agonist Potency and Selec-tivity at Human Melanocortin 1 Receptor 1b: The Role of Trp9 in Molecular Recognition. Biopolymers 89; 5: 401-408. [serial online] 9 Oktober 2007. [cited 2009 Apr 12]. Available from: URL: http://www3.interscience.wiley.com/cgi-bin/fulltext/11632 8610/PDFSTART.

13.Suzuki I, Tada A, Ollmann MM, Barsh GS, Im S, Lamoreux ML, et al. Agouti Signaling Protein Inhibits Melanogenesis and the Response of Human Melanocytes to $\alpha$-Melanotropin. J Invest Dermatol 108; 6: 838-842. [serial online] 1997. [cited 2009 Apr 12]. Available from: URL: http://www.ncbi.nlm.nih.gov/pubmed/9182807

14.Lu D, Willard D, Patel IR, Kadwell S, Overton L, Kost T, et al. Agouti Protein is an Antagonist of the MelanocyteStimulating-Hormone receptor. Nature 371: 799-802, [serial online] 1994. [cited 2009 Jun 10]. Available from: URL: http://www.nature.com/nature/journal/v3 71/n6500/pdf/371799a0.pdf

15.Bolognia JL and Orlow SJ. Pigmentary Disorders: Melanocyte Biology. Skin Biology 65: 935-945. [serial online]. [cited 2009 Jun 13]. Available from: URL: http://www.dermtext.com/storedfiles/Chapter65.pdf?CFID $=4686617 \& \mathrm{CF}$
TOKEN=10641747.

16.Busca R and Ballotti R. Cyclic AMP a Key Messenger in the Regulation of Skin Pigmentation. Pigment Cell Res 13: 6069. [serial online] 2000. [cited 2009 Jun 10]. Available from: URL: http://www3. interscience.wiley.com/cgi-bin/fulltext/11 9186451/PDFSTART.

17.Bertolotto C, Abbe P, Hemesath TJ, Bille K, Fisher DE, et al. Microphthalmia Gene Product as a Signal Transducer in cAMP-Induced Differentiation of Melanocytes. J Cell Biol 142; 3: 827-835. [serial online] 1998. [cited 2009 Jun 03]. Available from: URL: http://jcb. rupress.org/cgi/re-print/142/3/827.

18.Passeron T, Valencia JC, Bertolotto C, Hoashi T, Le Pape E, Takahashi K, et al. SOX9 is a key player in ultraviolet Binduced melanocyte differentiation and pigmentation. PNAS 104; 35: 13984 13989. [serial online] Aug 28 2007. [cited 2009 Apr 25]. Available from: URL: http://www.pnas.org/content/104/35/1398 4.full.pdf+html.

19.Alonso S, Izagirre N, Zubiaga-Smith I, Gardeazabal J, Luís Díaz-Ramón J, Díaz-Pérez JL, et al. Complex signatures of selection for the melanogenic loci TYR, TYRP1 and DCT in humans. BMC Evolutionary Biology 8; 74: 1-14. [serial online] Feb 28, 2008. [cited 2009 Jun 13]. Available from: URL: http://www.bio medcentral.com/content/pdf/1471-21488-74.pdf

20.Slominski A. Coming of Age of Melanogenesis-Related Proteins. Arch Pathol Lab Med 126: 775-777 [serial online] July 2002. [cited 2009 Jun 13]. Available from: URL: http://arpa.allenpress.com/ pdfserv/10.1043\%2F00039985(2002)126 \%3C0775:COAOMR\%3E2.0.CO\%3B2.

21.Costin GE and Hearing VJ. Human skin pigmentation: melanocytes modulate skin color in response to stress. Faseb J 21: 976-994. [serial online] 2007. [cited 2009 Jun 13]. Available from: URL: http:// www.fasebj.org/cgi/reprint/ 21/4/976.pdf

22.Valverde P, Healy E, Jackson I, Rees JL, Thody AJ. Variants of the melanocytestimulating hormone receptor gene are associated with red hair and fair skin in humans. Nat. Genet. 11 (3): 328-30. [serial online] 1995. [cited 2009 Apr 12]. Available from: DOI: 10.1038/ng1195- 
328.PMID 7581459

23.Harding RM, Healy E, Ray AJ, Ellis NS, Flanagan N, Todd C, et al. Evidence for Variable Selective Pressures at MC1R. Am J Hum Genet 66:1351-1361. [serial online] 2000. [cited 2009 Apr 22]. Available from: URL: http://www.pubmedcentral.nih.gov/picrender.fcgi?artid= 1288200\&blobtype $=$ pdf

24.Fernandez LP, Milne RL, Bravo J, Lopez JM, et al. MC1R: three novel variants identified in a malignant melanoma association study in the Spanish population. Carcinogenesis 28;8: 1659-1664, [serial online] 2007. [cited 2009 Jun 23]. Available from: URL: http://carcin. oxford-journals.org/cgi/reprint/28/8/1659

25. Valverde P, Healy E, Sikkink S, Haldane F, Thody AJ, Carothers A, et al. The Asp84Glu variant of the melanocortin 1 receptor (MC1R) is associated with melanoma. Human Molecular Genetics 5;10: 1663-1666, [serial online] 1996. [cited 2009 Jun 23]. Available from: URL: http://hmg.oxfordjournals.org/cgi/ reprint $/ 5 / 10 / 1663$
26.Abdel Malek ZA, Kadekaro AL, Kavanagh RJ, Todorovic A, Koikov LN, McNulty JC, et al. Melanoma prevention strategy based on using tetrapeptide $\alpha-\mathrm{MSH}$ analogs that protect human melanocytes from UV-induced DNA damage and cytotoxicity. Faseb J 20: E888-E896, [serial online] 2006. [cited 2009 Jun 23]. Available from: URL: http://www.fasebj.org/cgi/reprint $/ 20 / 9 / 1561$

27.Hedstrand H, Ekwall O, Olsson MJ, Landgren E, Kemp EH, Weetman P, et al. The transcription factors SOX9 and SOX10 are vitiligo autoantigens in autoimmune polyendocrine syndrome type I. The Journal of Biological Chemistry: Manuscript no: M102391200, [homepage on the Internet] Jun 22 2001. [cited 2009 Jun 23]. Available from: http://www. jbc.org/cgi/reprint/M102391200v1.pdf

28.Susan Taylor's Brown skin net. Skin: vitiligo. [homepage on the Internet] updated 2009. [cited 2009 Jun 23]. Available from: http://brownskin.orbius. com/default.home 